\title{
PENCEGAHAN DINI TERHADAP PENYAKIT TIDAK MENULAR (PTM) MELALUI GERMAS
}

\author{
Yarmaliza $^{1)}$, Zakiyuddin ${ }^{1)}$ \\ ${ }^{1)}$ Fakultas Kesehatan Masyarakat Universitas Teuku Umar \\ email: yarmaliza@utu.ac.id, zakiyuddin@utu.ac.id
}

\begin{abstract}
ABSTRAK
Penyakit Tidak Menular (PTM) merupakan salah satu masalah kesehatan yang telah menjadi perhatian nasional maupun global. Morbiditas dan Mortalitas PTM semakin meningkat di Indonesia. Data kematian menurut World Health Organization (WHO) menunjukkan bahwa dari 57 juta kematian di dunia pada tahun 2014, sebanyak 36 juta disebabkan oleh PTM. Penyakit kardiovaskular merupakan PTM penyebab kematian terbesar yaitu sebesar 39\%.. Sebesar 70\% dari populasi global akan meninggal akibat PTM seperti jantung, stroke, diabetes mellitus, kanker. Prevalensi PTM di Indonesia menurut Survei Kesehatan Rumah Tangga (SKRT) tahun 2012 pada kelompok usia 25-34 tahun adalah 9,3\% dan meningkat seiring betambahnya usia pada kelompok usia 53-64 tahun sebesar 15,5\%. Salah satu bentuk upaya pemerintah dalam menurunkan angka penyakit menular maupun tidak menular adalah melalui intruksi presiden no.01 tahun 2017 tentang Gerakan Masyarakat Hidup Sehat (GERMAS). Masih rendahnya kesadaran masayarakat terhadap gaya hidup sehat, masih banyak terdapat masyarakat yang memilikki faktor resiko, masih kurangnya informasi terkait GERMAS. Masih rendahnya dukungan dan motivasi lintas sektoral terhadap penggalakkan GERMAS. Kegiatan pengabdian ini dapat meningkatkan kesadaran masyarakat terhadap gaya hidup sehat, meningkatkan pemahaman masyarakat akan pentingnya untuk mengetahui faktor resiko, meningkatkan informasi terkait GERMAS, meningkatkan dukungan dan motivasi lintas sektoral terhadap penggalakkan GERMAS pada masyarakat.
\end{abstract}

Kata kunci: PTM, GERMAS, penyuluhan

\begin{abstract}
ABSTARCT
Non-communicable disease (PTM) is one of the health problems that has become a national and global concern. PTM morbidity and mortality is increasing in Indonesia. Death data according to the World Health Organization (WHO) shows that of the 57 million deaths in the world in 2014, 36 million were caused by PTM. Cardiovascular disease is the largest PTM cause of death by $39 \%$. As many as $70 \%$ of the global population will die from PTM such as heart disease, stroke, diabetes mellitus, cancer. The prevalence of PTM in Indonesia according to the Household Health Survey (SKRT) in the 25-34 year age group is $9.3 \%$ and increases with increasing age in the 53-64 year age group of 15.5\%. One form of the government's efforts to reduce the number of infectious and non-communicable diseases is through presidential instruction no. 2017 in 2017 on the Movement for Healthy Living Society (GERMAS). The community's low awareness of a healthy lifestyle, there are still many people who have risk factors, there is still a lack of information regarding GERMAS. Low crosssectoral support and motivation for GERMAS promotion. This service activity can increase public awareness of healthy lifestyles, increase public understanding of the importance of knowing risk factors, improve information related to GERMAS, increase cross-sectoral support and motivation for GERMAS promotion in the community.
\end{abstract}

Keywords: PTM, GERMAS, counseling 


\section{PENDAHULUAN}

Indonesia saat ini di hadapi dengan tantangan besar yakni masalah kesehatan triple burden, karena masih adanya penyakit infeksi, meningkatnya penyakit tidak menular (PTM) dan penyakit-penyakit yang seharusnya sudah teratasi muncul kembali. Pada era 1990, penyakit menular seperti ISPA, Tuberkulosis dan Diare merupakan penyakit terbanyak dalam pelayanan kesehatan. Namun, perubahan gaya hidup masyarakat menjadi salah satu penyebab terjadinya pergeseran pola penyakit (transisi epidemiologi). Tahun 2015, penayakit tidak menular (PTM) seperti stroke, penyakit jantung koroner (PJK), kanker dan diabetes justru menduduki peringkat tertinggi.

Dalam 4 (empat) tahun terakhir terjadi pergeseran pola penyakit. Jika dulu penyakit menular merupakan penyakit terbanyak dalam pelayanan kesehatan, saat ini bergeser, Penyakit tidak menular yang memiliki proporsi utama, hal ini merupakan fenomena yang terjadi pada negara berkembang seperti Indonesia. Hal ini terjadi akibat perubahan pola hidup masyarakat, pola hidup yang tidak sehat, kurangnya aktivitas fisik dan kebiasaan makan yang tidak baik merupakan penyebab penyakit tidak menular semakin meningkat.

Meningkatnya PTM dapat menurunkan produktivitas sumber daya manusia, bahkan kualitas generasi bangsa. Hal ini berdampak pula pada besarnya beban pemerintah karena penanganan PTM membutuhkan biaya yang besar. Pada akhirnya, kesehatan akan sangat mempengaruhi pembangunan sosial dan ekonomi. Penduduk usia produktif dengan jumlah besar yang seharusnya memberikan kontribusi pada pembangunan, justru akan terancam apabila kesehatannya terganggu oleh PTM dan perilaku yang tidak sehat

Berubahnya gaya hidup manusia karena adanya urbanisasi, modernisasi, dan globalisasi telah menyebabkan terjadinya peningkatan Penyakit Tidak Menular (PTM). Penyakit tidak menular telah menjadi penyebab utama kematian secara global pada saat ini (Shilton, 2013). Data WHO menunjukkan bahwa sebanyak 57 juta (63\%) angka kematian yang terjadi di dunia dan 36 juta (43\%) angka kesakitan disebabkan oleh Penyakit Tidak Menular. Global status report on NCD World Health Organization (WHO) tahun 2010 melaporkan bahwa 60\% penyebab kematian semua umur di dunia adalah karena PTM dan 4\% meninggal sebelum usia 70 tahun. Seluruh kematian akibat PTM terjadi pada orang-orang berusia kurang dari 60 tahun, 29\% di negaranegara berkembang, sedangkan di negaranegara maju sebesar 13\% (Remais, 2012)

Salah satu bentuk upaya pemerintah dalam menurunkan angka penyakit menular maupun tidak menular adalah melalui intruksi presiden no.01 tahun 2017 tentang Gerakan Masyarakat Hidup Sehat (GERMAS), yang merupakan suatu tindakan sistematis dan terencana yang dilakukan secara bersama-sama oleh seluruh komponen bangsa dengan kesadaran, kemauan dan kemampuan berperilaku sehat untuk meningkatkan kualitas hidup. Pelaksanaan GERMAS harus dimulai dari keluarga, karena keluarga adalah bagian terkecil dari masyarakat yang membentuk kepribadian. GERMAS mengajak masyarakat untuk membudayakan hidup sehat, agar mampu mengubah kebiasaan-kebiasaan atau perilaku tidak sehat.

Indonesia sedang mengalami perubahan pola penyakit atau yang sering disebut transisi epidemiologi, ditandai dengan meningkatnya kematian dan kesakitan akibat penyakit tidak menular (PTM) seperti stroke, jantung, kanker dan lain-lain. Sementara itu, kesakitan dan kematian akibat penyakit menular semakin menurun, walaupun prevalensi penyakit masih cukup tinggi. Kecenderungan kesakitan dan kematian akibat PTM ini menyebabkan tingginya kebutuhan masyarakat akan pelayanan kesehatan, terutama pelayanan rujukan di rumah sakit. 
Meningkatnya kasus PTM akan menambah beban pemerintah dan masyarakat karena penanganannya membutuhkan biaya yang besar dan memerlukan teknologi tinggi. Biaya untuk pengobatan PTM yang sangat besar dapat menyebabkan kemiskinan (pengeluaran katastropik). Selain itu, kecacatan dan kematian yang disebabkan oleh kasus PTM juga menyebabkan hilangnya potensi/modal sumber daya manusia dan menurunnya produktivitas (productivity loss) yang pada akhirnya akan mempengaruhi pembangunan sosial dan ekonomi.Tanpa upaya yang signifikan, kecenderungan kesakitan dan kematian serta permintaan pelayanan kesehatan akan terus meningkat, didorong oleh perubahan pola hidup masyarakat yang cenderung tidak aktif secara fisik, konsumsi buah dan sayur yang rendah serta konsumsi rokok dan alkohol. Risiko PTM juga menjadi semakin tinggi karena transisi demografi, yaitu semakin meningkatnya proprosi dan jumlah penduduk dewasa dan lanjut usia yang rentan terhadap PTM dan penyakit degeneratif.

Berdasarkan data yang di peroleh dari organisasi kesehatan dunia (WHO) 2012 menunjukkan bahwa angka penyakit tidak menular mencapai 68 persen penyebab kematian secara global. PTM merupakan penyebab utama kematian di semua daerah kecuali Afrika, tapi proyeksi saat ini menunjukkan bahwa pada tahun 2020 peningkatan terbesar dalam kematian PTM akan terjadi di Afrika. Di negara Afrika kematian karena PTM diproyeksikan melebihi kematian dari penyakit menular, gizi dan kematian ibu dan perinatal sebagai penyebab paling umum kematian pada tahun 2030 (WHO, 2013).

Menurut penelitian yang dilaksanakan di Inggris, lebih dari $80 \%$ pasien berumur $\geq 45$ tahun yang baru didiagnosis mengidap DM setelah 10 tahun diobservasi ternyata memiliki resiko komplikasi penyakit jantung koroner $>5 \%, 73 \% \quad(45 \%$ sampai $92 \%)$ memiliki penyakit hipertensi, dan 73\% (45-92\%) memiliki konsentrasi kolesterol $>5$ $\mathrm{mmol} / \mathrm{l}$ (Lawrence et al., 2001). Kegiatan pengabdian masyarakat ini bekerjasama dengan aparat desa dan masyarakat gampong Jati Rejo, Kecamatan Kuala Trang, Kab. Nagan Raya.

Berdasarkan survei yang telah dilakukan, terlihat bahwa penyakit tidak menular (PTM) pada masyarakat gampong Jati Rejo masih cukup tinggi, seperti penyakit diabetes melitus, kolesterol, asam urat dan penyakit jantung. Usia rata-rata berada pada usia $35 \mathrm{ke}$ atas, dari hasil wawancara dengan beberapa warga yang menderita penyakit tidak menular diperoleh informasi bahwa mereka kurang mengetahui faktor resiko yang dapat menyebabkan terjadinyan PTM, sehingga ini akan berdampak pada prilaku yang tidak sehat. Permasalahan tersebut muncul dikarenakan kurangnya partisipasi masyarakat dalam kegiatan yang lakukan oleh instansi terkait, sehingga masyarakat tidak memilikki informasi yang benar-benar dibuthkan, terutama terkalit PTM.

Kegiatan pengabdian ini dilakukan untuk memberikan informasi atau pengetahuan bagi masyarakat Gampong Pasie Mesjid terkait penyakit tidak menular. 


\section{TINJAUAN PUSTAKA}

Penyakit tidak menular disingkat PTM juga dikenal sebagai penyakit kronis, tidak ditularkan dari orang ke orang. Penyakit tidak menular pada manusia mempunyai durasi panjang dan perkembangan umumnya lambat. 4 jenis penyakit tidak menular menurut WHO adalah penyakit kardiovaskular (seperti serangan jantung dan stroke), kanker, penyakit pernapasan kronis (seperti penyakit obstruksi paru kronis dan asma) dan diabetes.

\section{Epidemi dan Prevalensi PTM}

Epidemiologi PTM sudah mempengaruhi negara-negara berpenghasilan rendah dan menengah di mana hampir 80\% dari kematian PTM atau sekitar 29 juta kematian telah terjadi. PTM adalah penyebab utama kematian di semua wilayah kecuali Afrika, namun proyeksi saat ini menunjukkan bahwa pada tahun 2020 peningkatan terbesar dalam kematian PTM akan terjadi di Afrika. Kematian yang terjadi di negara-negara Afrika, PTM diproyeksikan melebihi kematian gabungan dari penyakit menular dan gizi, kematian maternal dan perinatal, sebagai penyebab paling umum kematian pada tahun 2030.

Kemiskinan terkait erat dengan angka kejadian epidemiologi penyakit tidak menular. Peningkatan pesat penyakit tidak menular diperkirakan menghambat inisiatif pengurangan kemiskinan di negara-negara berpenghasilan rendah. Orang yang rentan dan kurang beruntung secara sosial akan sakit dan mati lebih cepat dari orang-orang dengan posisi sosial yang lebih tinggi, terutama karena mereka berada pada risiko lebih besar untuk terkena produk yang berbahaya, seperti tembakau atau makanan tidak sehat, dan memiliki akses terbatas ke layanan kesehatan. Dalam pengaturan sumber daya rendah, biaya kesehatan untuk penyakit jantung, kanker, diabetes atau penyakit paru-paru kronis sangat menguras biaya, sehingga mendorong masyarakat ke dalam kemiskinan.

\section{Pencegahan penyakit tidak menular secara Umum}

\section{1) Mempertinggi nilai kesehatan}

Cara meningkatkan nilai kesehatan dapat ditempuh dua cara yaitu melalui usaha kesehatan ( hygiene) perorangan dan usaha kesehatan lingkungan (sanitasi)

Usaha Kesehatan (hygiene) Perseorangan yaitu lebih menitikberatkan kepada usaha peningkatan nilai kesehatn perorangan.

Contoh dari kesehatan perorangan adalah: Dengan makan makanan yang memenuhi gizi, Merebus air hingga matang, Menggosok gigi secara teratur, Memasak makanan dengan memperhatikan gizinya, Mencuci tangan sebelum memegang makanan, Menutup tempat air yang ada di rumah, Tidak makan sembarangan, istirahat yang cukup, Pemeriksaan kesehatan tubuh kita secara berkla (Ichsan, Yuliati, Rejeki, 1993).

Usaha Kesehatan Lingkungan (sanitasi) usaha yang lebih menitikberatkan kepada kepribadian lingkungan hidup secara fisik atau kepada faktor lingkungan yang mempengaruhi kesehatan perorangan atau masyarakat.

Contoh usaha kesehatan lingkungan dengan cara sanitasi adalah :
a) Membuat jamban keluarga ( MCK )
b) Penyediaan sumber air minum yang bersih
c) Pembuatan tempat pembuangan sampah
d) Pengendalian pencemaran tanah, udara dan air
e) Serta pengawasan terhadap sector penyebar penyakit 


\section{2) Pemeriksaan Kesehatan Berkala}

Pemeriksaan kesehata secara berkala merupakan suatu upaya untuk mencegah munculnya atau menyebarnya suatu penyakit. Melalui upaya ini, kemungkinan munculnya wabah dapat diditeksi sedini mungkin. Di samping itu, melalui upaya ini masyarakat akan mendapatkan pengarahan rutin yang berkaitan dengan perawatan kesehatan, penanganan suatu penyakit, usaha mempertinggi nilai kesehatan, dan mendapatkan vaksinasi.

\section{3) Pola Hidup Sehat}

Dengan GERMAS merupakan salah satu upaya untuk memperkecil terjadinya PTM, pola makan sehat, hindari makanan yang banyak mengandung lemak atau yang mengandung kolesterol tinggi. Seafood memiliki kandungan kolesterol tinggi yang dapat membahayakan jantung. Hindari prilaku merokok untuk kesehatan jantung, maka segera hentikan kebiasaan ini agar jantung tetap sehat. Stres juga harus dihindari, karena di saat seseorang mengalami stres tubuhnya akan mengeluarkan hormon cortisol yang menyebabkan pembuluh darah menjadi kaku. Hormon norepinephrine akan diproduksi tubuh saat menderita stres, yang akan mengakibatkan naiknya tekanan darah. Maka, sangat baik bila Anda menghindari stres baik di kantor atau di rumah. Pola hidup sehat juga dapat juga dilakukan seperti kegiatan olahraga (berjalan kaki, jalan cepat, atau jogging).

\section{METODE PELAKSANAAN}

Kegiatan ini dilaksanakan dalam bentuk promosi sebagai salah satu bentuk penyuluhan dan pembelajaran bagi ibu - ibu yang bertempat tinggal Gampong Jati Rejo, Kecamatan Kuala Pesisir Kab. Nagan Raya. Penyuluhan telah dilaksanakan pada tanggal 24 Maret 2018. Metode pendekatan yang digunakan dalm pengabdian ini adalah melalui sosiallisasi dan penyuluhan pada masyarkat dengan melibatkan lintas sektoral.

a.Rencana kegiatan yang dilakukan berbentuk Forum Group Discusion (FGD) yang nantinya akan di lanjutkan dengan menonton bersama sebuah video seputar prilaku hidup sehat yang mencerminkan bagian dari pada tujuan GERMAS dalam rangka mencegah penyakit, khususnya penyakit tidak menular

b.Partisipasi warga dalam kegiatan pengabdian ini berupa keterlibatan masyarakat dan lintas sektoral dalam forum diskusi, sehingga ajang diskusi ini diharapkan dapat menggali masalah yang terdapat di tengah masyarakat. Lebih jauh lagi, kegiatan pengabdian ini juga diharapkan dapat menjadi informasi serta bahkan menjadi masukkan bagi masyarakat, khususnya bagi lintas sektoral dalam mengenal masalah yang ada pada warga atau masyarakat, berikut dapat merancang atau memformulasi solusi sesusi dengan masalah yang ada.

\section{HASIL DAN PEMBAHASAN}

Pengabdian kepada masyarakat dengan judul penyuluhan preventif secara dini terhadap penyakit tidak menular (PTM) melalui GERMAS bertujuan untuk meningkatkan kesadaran perilaku sehat ibu dalam pencegahan penaykit tidak menular di Gampong Jati Rejo, Kecamatan Kuala Pesisir Kab. Nagan Raya

Kegiatan ini dihadiri oleh $20 \mathrm{ibu}$, tanggapan dari para ibu terhadap kegiatan ini cukup baik sekali, ini di buktikan dengan antusias mereka untuk berhadir pada saat penyuluhan berlangsung serta peran aktif para ibu pada saat diskusi. Pelaksanaan 
pengabdian masyarakat ini dilakukan dengan memberikan penyuluhan tentang upaya peningkatan perilaku sehat ibu dalam pencegahan penyakit tidak menular melalui GERMAS, dilanjutkan dengan memberi banyak contoh dalam kehidupan sehari-hari cerminan prilaku yang beresiko terkena penaykit tidak menular, seperti tidak menjaga pola makan, tidak berolahraga, dan tidak cukup istirahat, tidak menggunakan alat pelindung diri (APD) pada saat bekerja, serta masih banyak hal lainnya yang tergolong dalam resiko untuk dapat terjadinya penyakit tidak menular. Di akhir kegiatan penulis juga memberikan bonus berupa brosur atau booklet yang menggambarkan tentang upaya peningkatan perilaku sehat ibu dalam pencegahan penyakit tidak menular.

Perilaku adalah respon individu terhadap suatu stimulus atau suatu tindakan yang dapat diamati dan mempunyai frekuensi spesifik, durasi dan tujuan dan baik disadari maupun tidak. Perilaku merupakan kumpulan berbagai faktor yang saling berinteraksi. Seiring dengan tidak disadari bahwa interaksi itu sangat kompleks sehingga kadangkadang kita tidak sempat memikirkan penyebab seseorang menerapkan perilaku tertentu. Karena itu amat penting untuk dapat menelaah alasan dibalik perilaku individu, selama ia mampu mengubah perilaku tersebut.

Menurut Becker konsep perilaku sehat ini merupakan pengembangan dari konsep perilaku yang dikembangkan Bloom. Becker menguraikan perilaku kesehatan menjadi tiga domain, yakni pengetahuan kesehatan (health knowledge), sikap terhadap kesehatan (health attitude) dan praktek kesehatan (health practice). Hal ini berguna untuk mengukur seberapa besar tingkat perilaku kesehatan individu yang menjadi unit analisis penelitian. Becker mengklasifikasikan perilaku kesehatan menjadi tiga dimensi.

Pengetahuan Kesehatan Pengetahuan tentang kesehatan mencakup apa yang diketahui oleh seseorang terhadap cara-cara memelihara kesehatan, seperti pengetahuan tentang penyakit menular, pengetahuan tentang faktor-faktor yang terkait. dan atau mempengaruhi kesehatan, pengetahuan tentang fasilitas pelayanan kesehatan, dan pengetahuan untuk menghindari kecelakaan.

Sikap terhadap kesehatan Sikap terhadap kesehatan adalah pendapat atau penilaian seseorang terhadap hal-hal yang berkaitan dengan pemeliharaan kesehatan, seperti sikap terhadap penyakit menular dan tidak menular, sikap terhadap faktor-faktor yang terkait dan atau mempengaruhi kesehatan, sikap tentang fasilitas pelayanan kesehatan, dan sikap untuk menghindari kecelakaan.

Praktek kesehatan Praktek kesehatan untuk hidup sehat adalah semua kegiatan atau aktivitas orang dalam rangka memelihara kesehatan, seperti tindakan terhadap penyakit menular dan tidak menular, tindakan terhadap faktor-faktor yang terkait dan atau mempengaruhi kesehatan, tindakan tentang fasilitas pelayanan kesehatan, dan tindakan untuk menghindari kecelakaan.

Selain Becker, terdapat pula beberapa definisi lain mengenai perilaku kesehatan. Menurut Solita, perilaku kesehatan merupakan segala bentuk pengalaman dan interaksi individu dengan lingkungannya, khususnya yang menyangkut pengetahuan dan sikap tentang kesehatan, serta tindakannya yang berhubungan dengan kesehatan. Sedangkan Cals dan Cobb mengemukakan perilaku kesehatan sebagai: "perilaku untuk mencegah penyakit pada tahap belum menunjukkan gejala (asymptomatic stage)".

Menurut Skinner perilaku kesehatan (healthy behavior) diartikan sebagai respon seseorang terhadap stimulus atau objek yang berkaitan dengan sehat-sakit, penyakit, dan faktor-faktor yang mempengaruhi kesehatan seperti lingkungan, makanan, minuman, dan pelayanan kesehatan. Dengan kata lain, perilaku kesehatan adalah semua aktivitas atau kegiatan seseorang, baik yang dapat diamati (observable) maupun yang tidak dapat 
diamati (unobservable), yang berkaitan dengan pemeliharaan dan peningkatan kesehatan. Pemeliharaan kesehatan ini mencakup mencegah atau melindungi diri dari penyakit dan masalah kesehatan lain, meningkatkan kesehatan, dan mencari penyembuhan apabila sakit atau terkena masalah kesehatan (Dwi, dkk, 2003)

Perilaku sehat adalah sifat pribadi seperti kepercayaan, motif, nilai, persepsi dan elemen kognitif lainnya yang mendasari tindakan yang dilakukan individu untuk memelihara dan meningkatkan kesehatannya, termasuk pencegahan penyakit, perawatan kebersihan diri, penjagaan kebugaran melalui olah raga dan makanan bergizi. Perilaku sehat diperlihatkan oleh individu yang merasa dirinya sehat meskipun secara medis belum tentu mereka betul-betul sehat.

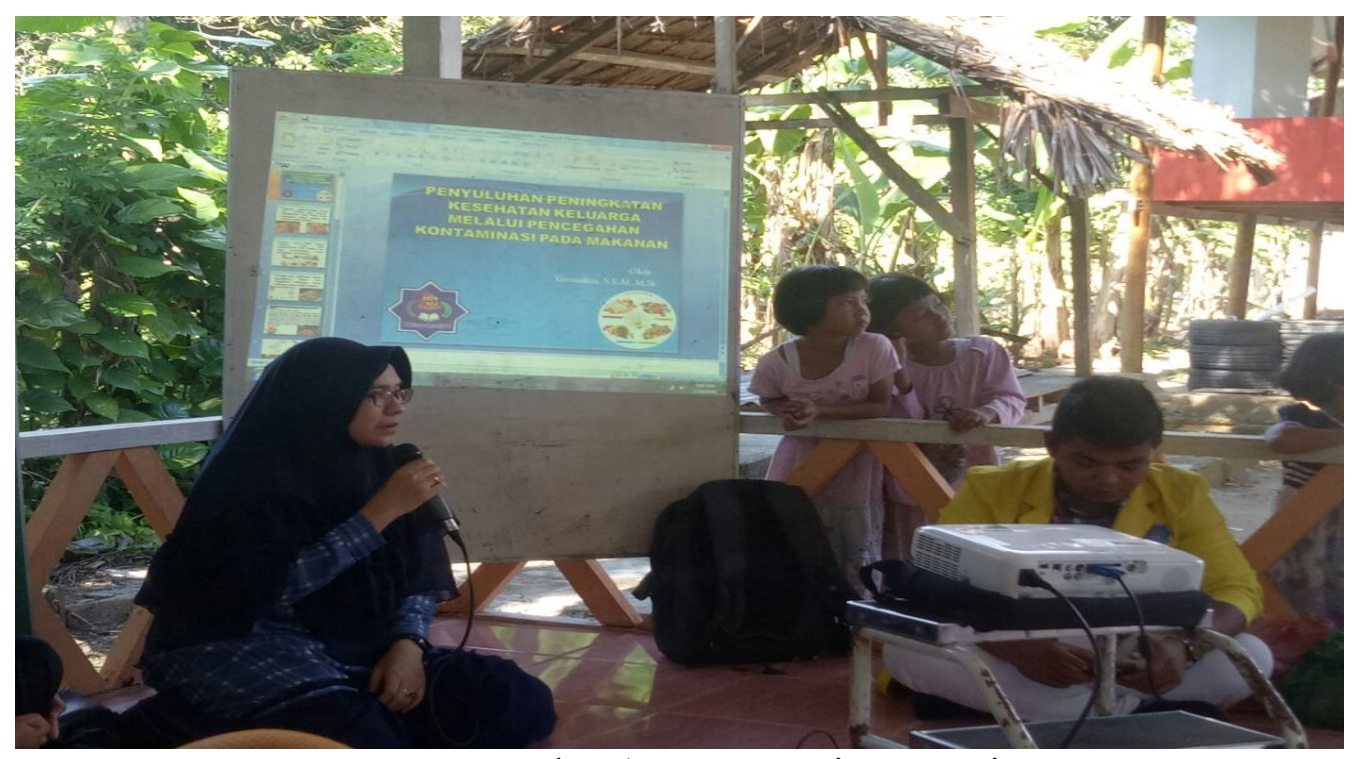

Gambar 1. Penyampaian materi

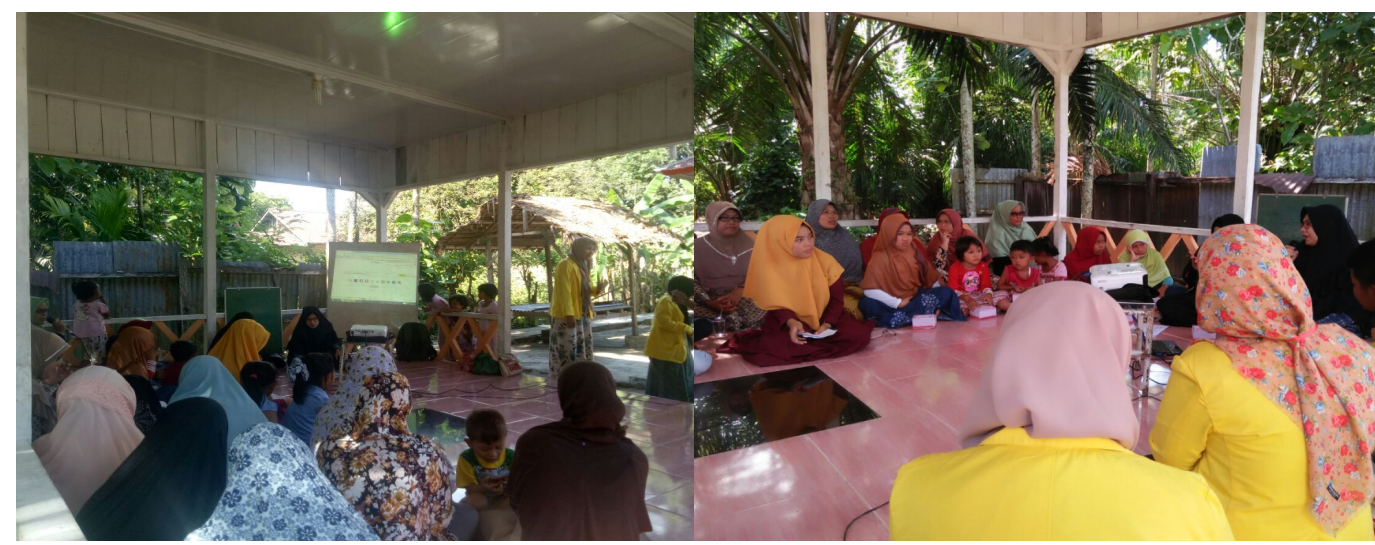

Gambar 2. Peserta mendengarkan materi 


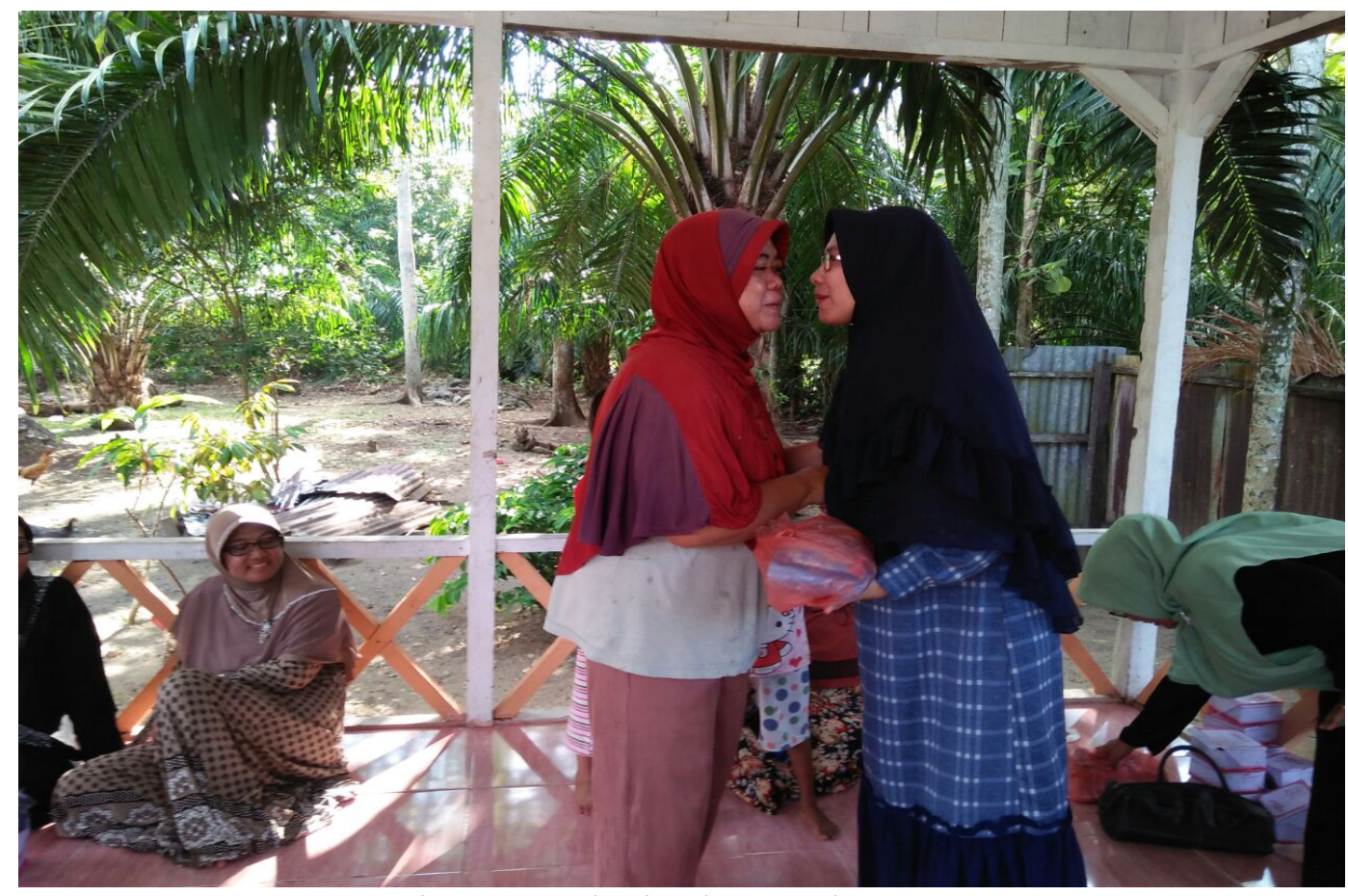

Gambar 3. Pemberian kenang-kenangan

\section{KESIMPULAN}

Kesehatan dengan perilaku sangatlah erat dan saling berhubungan, individu yang sehat akan tercermin dari perilaku yang sehat pula, begitu juga dengan perilaku yang sehat akan mencerminkan individu dengan kualitas hidup yang baik. Kesadaran bagi para ibu akan pentingnya prilaku sehat dalam mencegah penyakit tidak menular melalui GERMAS sangat diperlukan, sehingga akan menjadi salah satu cara dalam menekan angka kesakitan, khususnya penyakit tidak menular, misalnya penyakit kolesterol, diabetes melitus, dan penyakit tidak menular lainnnya.

\section{DAFTAR PUSTAKA}

[5]. Basuki E., 2005. Penyuluhan Diabetes Melitus. Jakarta, Balai Penerbit FK UI, pp. 131-35.

[6]. Dwi Retno A., Soedirman, dan Suyoto, 2002. Dermatofotosis Pada Penderita DM Tipe II : Pengaruh Kontrol Gula Darah, Obesitas, dan Durasi Sakit. Berkala Ilmu Kedokteran.34:22-9

[7]. Jazilah, 2003. Hubungan Tingkat Pengetahaun, Sikap dan Praktik (PSP) Penederita Diabetes Melitus Mengenai Pengelolaan Diabetes Melitus dengan Kendali Kadar Glukosa Darah. Tesis Megister Ilmu Kesehatan (Gizi dan Kesehatan). Pascasarjana Universitas Gajah Mada, Yogyakarta.

[8]. Jazilah, Paulus Wijono, Toto Sudargo, 2005. Hubungan Tingkat Pengetahaun, Sikap dan Praktik (PSP) Penderita Diabetes Melitus Mengenai Pengelolaan Diabetes Melitus dengan Kendali Kadar Glukosa Darah. Sains Kesehatan Program Pasca Sarjana Universitas Gajah Mada.16:213-222.

[9]. Nasriati R. Stress dan perilaku pasien dm dalam mengontrol kadar gula darah. tidak diterbitkan. Skripsi. Ponorogo; Ilmu Keperawatan Universitas Muhammadiyah Ponorogo; 2013 